\title{
The Romani Ethos: A Transnational Approach to Romani Literature
}

\section{Ana Belén Martín Sevillano}

ab.martin.sevillano@umontreal.ca

Tenured Associate Professor

Université de Montréal

ORCID: https://orcid.org/0000-0001-7829-3067

Ana Belén Martín Sevillano received her BA and PhD in Hispanic Philology from Universidad Complutense de Madrid, specializing in Latin American Literature and Culture. Her research focuses on issues related to diaspora, "race"/ethnicity, and gender in Spain and Latin America. In 2014 she received an endowment from the Canadian Social Sciences and Humanities Research Council to work on her project The Emergence of the Hispano-Romani Literature: The Writing of Ethnicity, Diaspora and Citizenship.

\section{Critical}

Romani Studies 


\section{Abstract}

In the context of the sociopolitical articulation of the Romani diaspora, this paper explores how its narrative is supported in four literary works written in different languages and national settings - Fires in the Dark by Louise Doughty, Camelamos Naquerar (We want to speak) by José Heredia Maya, Goddamn Gypsy by Ronald Lee, and Dites-le avec des pleurs (Say it with tears) by Mateo Maximoff - shaping a transnational/diasporic literary production. Departing from the existence of a common Romani ethos, the analysis focuses on how these literary works shape a transnational/diasporic literature by representing the specificities of the Romani history - in particular the recollection of traumatic collective experiences - through a number of narrative strategies, such as self-representation or the depiction of cultural memory.

\section{Keywords}

- Culture

- Ethos

- History

- Romani literature

- Self-representation

- Transnational

- Trauma 


\section{Introduction}

The idea of the existence of a transnational/diasporic Romani community has been central to establishing the ethnopolitical credo of the Romani movement (Vermeersch 2006), which demands rights for all Roma. The legal claims of all the instances and associations comprised under such a denomination emerge from the notion that dispersed Romani groups are linked not only by a common origin but also by a shared experience of discrimination and persecution. At the same time, the ethnopolitical discourse of the Romani movement nurtures the idea of the distinct cultural specificity of all Roma, regardless of their national ascription, specific history, or mother tongue. Still, disparities among the numerous Romani communities are undeniable, and so is their internal heterogeneity. The narrative(s) of the Romani diaspora, and of its pitfalls, is articulated in political, legal, historical, and cultural/literary texts that, whether oral or written, depart from the need to configure new and diverse representations of what it means to be Roma. These new representations convey Roma's diversity and heterogeneity by considering individual experiences, transcending the essentialism that ethnic identities might entail. Depicting Roma as a plural array of groups whose members are distinct individuals, with a particular experience and understanding of the world, has an impact both on how Roma are socially perceived and on how they might perceive themselves. In this context, this article initially elaborates the notion of a transnational Romani Literature. In order to support the existing connection among the range of literary works that would comprise a transnational Romani literature, the analysis of the texts builds on the notion of ethnic ethos, which is deployed through a number of thematic and representational strategies.

\section{On Romani Literature and Ethos}

As a cultural entity, Romani literature is still in the making. Critical studies on this subject usually build on methodological nationalism. This would be the case of the foundational work of Rajko Djuric (2002), who mapped the literary activity of Romani authors in Europe, sorting them out by nationalities. More recently, other scholars (Toninato 2014; Blandfort 2015; French 2015; Zahova 2016, 2020) equally have resorted to linguistic or national frames to describe or analyse Romani literary practices. These scholars draw attention to the plural and hybrid character of Romani writing, pointing out a number of common conceptual and thematic threads that transcend location and language. These commonalities often are linked to the ethnopolitical character of the texts that delve into issues related to identity politics and cultural memory. In particular, Toninato's study departs from and implements a transnational perspective in the analysis and then resorts to the national or regional frame to map literary production $(2014,74-$ 89). One of its chapters is fully consecrated to consider the complexity and difficulty of critically framing Romani literature, pondering the pertinence of applying categories such as ethnic, migrant, or minor (Ibid., 115-126). I agree with Toninato that, while critical branding might be methodologically effective, it might essentialize and fail to value the complexity of Romani writing practices.

Certainly, the notion of literature, closely linked to that of language, has been traditionally ascribed to national territories. The nation remains today the primary taxonomic criterium when sorting, whether for commercial or analytical purposes, literary practices. Specialized studies, such as those abovementioned, usually accord a double attribution to the work authored by Roma: it belongs at once to Romani 
literature, regardless of the language in which it is written, and to that of the country of origin of the author. However, Romani authors have received little recognition in national literary accounts, and they remain largely unknown, which suggests that locating and framing their works in the context of national literatures reduces their reach and impact. Louise Doughty (b. 1963), a well-published English author of Romani descent, pointed out in an interview that, regrettably, the two literary pieces in which she explored Romani history, both in Central Europe and in England, were not as well received, particularly in terms of sales, as the rest of her novels (Smith 2018).

It is the premise of this article that constructing the notion of the Romani literature in parallel to that of the Romani diaspora helps to articulate a more compelling approach to Romani literary practices. A transnational and multilingual frame would not just reveal the complex nature of these works but also highlight how they emerge from related positions and viewpoints, and how they represent analogous experiences. This approach is by no means new; in 1998, the publication of The Roads of the Roma, A PEN Anthology of Gypsy Writers suggested the existence of a transnational Romani literature. As explicitly indicated in the title, the main selection criterium was the ethnic ascription of the international cast of authors, whose texts had been originally written in an array of languages. Two of the editors of this anthology, Ian Hancock and Rajko Djuric, are renowned Romani scholars and activists, notorious for their sociocultural and political engagement; the third, Siobhan Dowd, the editor for PEN International, was a conscientious supporter of minority literatures and a writer herself. At the same time, it is undeniable that the very idea of a transnational literature, as appealing as it might be, poses challenges due to a number of important factors, such as the scarcity of available translations, which has an enormous impact on readership or commercial production and distribution. I am also quite aware of the many glitches and limitations of considering a transnational perspective that is limited by the few languages that I can read. Still, I expect this analysis to be a single piece in a larger puzzle of academic works that, as a whole, will reveal a coherent total picture of what makes up transnational Romani literature. Thus, my approach to the idea of a Romani literature goes beyond the limits imposed by territoriality, language, or the author's ethnic ascription as it focuses on the nature of the text, and how it discusses issues related to the embodied experience of being Roma. The analysis in this article implements a methodological frame that escapes the nation, or the language for that matter, as an analytical unit, proposing a new drawing of what Romani literature is today: a transnational multilingual body of works that register the Romani experience of the world through the very lens of that experience. For that purpose, the analysis will consider literary works, written in different languages and countries, that develop an aesthetic and a viewpoint that belong to the particular Romani ethos: Camelamos Naquerar (1976) by José Heredia Maya, Goddamn Gypsy (1971) by Ronald Lee, Dites-le avec des pleurs (1990) by Mateo Maximoff, and Fires in the Dark (2003) by Louise Doughty.

As defined by Baumlin and Meyer, the idea of ethos entails an idiosyncratic "cultural and embodied" narrative that comprises the subject's position in society $(2018,1)$. It is our thesis that many of the diverse and disperse literary practices authored by Roma reveal a common ethos, which in turn would be shared - at least to some extent - by the various groups comprised under the denomination of Roma. This ethos emerges from a set of values instilled by the practice of the Romaniya, ${ }^{[1]}$ from the preservation of 
their own oral and material culture (preserved by collective and domestic rites), from the distinct ethnic consciousness that Roma possess, and from the continuous and common experience of marginalization and persecution. After Reynolds, we consider ethos "as a social act and as a product of a community's character" $(1993,327)$. As other oppressed social groups, Roma are claiming their own voice by validating their marginal position in society, and by asserting in their discourse the rhetorical authority that emerges from that very social locus (Ibid., 330). Specifically, in literary practices, the Romani ethos is established by a number of elements, such as:

1. the recovery and assertion of Romani history;

2. the renewal of Roma's social representations through self-representation, legitimizing from within previously misconstrued behaviours or practices;

3. the vindication of a culture that has been misunderstood and despised;

4. the reconstruction of a language that has been considered a fabricated devious tool.

These elements often are intertwined and appear embedded in the texts written by Roma, which offer an embodied insider's account of historical episodes and social experiences while simultaneously reformulating social representations. Departing from the notion of the common ethos, this analysis is articulated in three sections that examine some of the key notions that shape this very ethos: history - in particular, the recollection of traumatic experiences - self-representation, and culture and language.

\section{Romani History, Memory, and the Narrative of Trauma}

Reconstructing Romani history is a challenging endeavor that is still in the making through interdisciplinary methodologies that involve historiographic, linguistic, or genetic research, among others. As an institutional discipline, historiography traditionally has ignored minority groups, and when it has recognized them, their representation in the historical discourse has not always been positive and certainly has never been informed by the views and voices of the members of those minority groups. Reconstructing Romani history from official documents that belong to the very systems that have oppressed Roma is also problematic. In the last few decades, the literary text has been an alternative site in which Roma are registering experiences that the historiographic discourse has obliterated or, worse, misconstrued. Additionally, fictional writing makes use of the results provided by the ongoing historical reconstruction in order to question or discuss them, as well as to embody experiences that the historical discourse can otherwise reduce to data and facts. Through the fictionalization of historical events, literary writing has the ability to fully depict the suffering of those that were despised for centuries. In this sense, literary studies have identified the prominence that the narrative of trauma has attained in the last few decades in texts authored by Roma. The Roads of the Roma anthology is certainly a revealing testimony to how the experience of trauma is a pivotal theme in Romani literature. In particular, and in parallel with political and legal discourses, literary discourse is paying attention to o baro porrajmos, the Roma Holocaust, which is still a controversial and understudied subject (Hancock 2002). The lack of political clout of the Roma and the scarcity of documentation, among other reasons, make this subject complex. The literary texts have become irreplaceable documents that represent the experience of Roma during the Nazi regime of terror and its expansion in Europe. For instance, Toninato dedicates a few pages to analyze 
the complexity behind the written representation of the Romani Holocaust (2004, 101-106). Likewise, in her study of Romani literature in German-speaking countries, French (2015) examines survivors' autobiographical accounts, pondering the impact that gender has in the process of reconstruction and representation. Blandfort (2013) points out that the Romani Holocaust has in fact become a cultural topos in French and German Romani literature. Thus, it could be argued that the Holocaust has become a founding trauma (LaCapra 2014, xii) for Romani communities, in the sense that the horrific experiences endured by Roma during the Nazi regime are at the source of the ethnopolitical Romani movement and its legal claims for rights and recognition.

In this context, Louise Doughty's Fires in the Dark offers a compelling fictional account of the Romani Holocaust by building on precise historical facts. The novel relies on a robust documentation to plausibly recreate the life of Roma who travelled the roads of Moravia and Bohemia during the first half of the twentieth century. This documentation not only informs the main plot but also is framed within it. Thus, the reader has an opportunity to verify within the actual limits of the literary text the transcript of those legal documents or managerial reports that had a shattering impact on the lives of many Roma, symbolically embodied by the novel's main characters. Doughty has declared that Fires in the Dark explored what could have been the story of her family had they not emigrated to England (Smith 2018). The space of fiction, together with historical documentation, allows the author to celebrate her origins by denouncing the cruel fate of those who, unlike her family, remained in the lands that they had travelled for centuries.

The plot of this historical fiction runs from 1927 to 1945, focusing on three generations of a Kalderash family that followed a seminomadic life in the Czech lands. Most of the narrative adopts the viewpoint of Anna, whose first childbirth opens the story. Indeed, motherhood serves as a rich allegory in the novel; on the one hand, it denotes the critical meaning that family bonds have in Romani culture and, on the other hand, it conveys that the fictional process of reconstructing Romani history is as strenuous and gratifying as giving birth to a human being. Anna's family initially endures the control that the authorities exerted on Roma shortly after the region declared its independence from the Austro-Hungarian Empire and became Czechoslovakia. Law No. 117 of 1927 ordained all Roma to be fingerprinted, registered, and forced to inform the authorities of their movements. It also prevented Roma from accessing certain areas and pushed them to live on the margins of a hostile society. After Nazi occupation of the country in 1938, the existing official records facilitated the genocide of Roma, who were confined in the Lety and Hodonín concentration camps, from where many were transported to Auschwitz. Kenrick reports that, out of a population of at least 40,000 Roma in the Czech lands, only 600 survived the Holocaust (2007, 60-61). The radically disturbing events that Roma endured in those camps are depicted in the novel through the fate of Anna and her family members.

The significance of this novel lies in how the horrific events that shaped Central European societies in the first half of the twentieth century are embodied by unusual fictional characters. The social destitution of Roma traditionally has excluded them from any non-discriminatory or complex social representation. Within the Western novelistic tradition, Roma were not only stereotyped but often animalized or reduced to immoral beings. In Fires in the Dark - as well as in Stone Cradle (2006) - Doughty depicts psychologically complex Romani characters, offering an extraordinary account of their experiences and providing access 
to a subjectivity that transcends ethnic or racial parameters. At the same time, the narrative in Fires in the Dark seamlessly flows between the characters' experiences and the insertion of the historical context in which those experiences take place.

In the first chapter, Josef, Anna's husband, a noble and caring man, witnesses the public announcement of the just enacted Law No. 117.

The Officer had paused to gain everybody's attention. He glanced at Josef. [...] The Officer continued amiably. 'All persons who have no fixed abode or who are of a nomadic inclination must present themselves immediately to the nearest authority of the state for the issuing of detailed identification. Each member of the family over the age of fifteen must attend, although all family members may be registered upon the identification papers of the head of the family. Prints of all five fingers on each hand will be required along with a physical description of each individual' (20).

Josef silently stares at the officer in charge of the announcement in front of a delighted crowd who welcomes the repressive practices that will eventually enable the massacre of thousands of human beings. Doughty conscientiously inserts a transcription/translation of the law within the narrative, conveying the historical, social, political, and legal frame that will allow the Holocaust to take place in Central Europe. At the same time, by focusing on the history of Anna and her family, Doughty places Roma at the center of one of the most traumatic episodes in Western history, revealing them as actual subjects, and agents, depicting a subjectivity that Roma had not owned until recently in literary texts.

The insertion of historical and legal text is a strategy that José Heredia Maya (1947-2010) also implemented in Camelamos naquerar (We want to speak) ${ }^{[2]}$ (1976), which addresses the mistreatment that Spanish Gitanos have endured. This hybrid piece was conceived as a flamenco musical to be recorded, at the same time, as a documentary. ${ }^{[3]}$ It comprises poetry (sung as flamenco), music, and dance, together with historical legal texts. The poems are fully articulated around the embodied experience of persecution and marginalization, which is unequivocally conveyed by the flamenco singing and dancing. From beginning to end the dominant tone is one of denouncement.

CAMELAMOS NAQUERAR es un espectáculo flamenco que tiene como objetivo exponer una situación de injusticia determinada. Hemos querido ceñirnos a la peculiar forma de racismo que con nosotros se sigue practicando desde que finalizado el siglo XV, los Reyes Católicos firmaron (...) una pragmática cruel e inhumana, tendente al exterminio de un grupo: el gitano (9). ${ }^{[4]}$

2 Camelamos naquerar is written in Spanish, with the occasional use of terms or expressions in Caló, such as the title itsef. Caló is the mixed language of the Spanish Gitanos, generally consisting of Romani vocabulary over a Spanish grammatical base.

3 A documentary version is available at https://www.youtube.com/watch?v=cOzi04RhC9k

4 Camelamos naquerar is a flamenco show that aims at presenting a specific situation of injustice. We chose to follow the very distinct form of racism that we have been enduring ever since, at the end of the fifteenth century, the Catholic monarchs signed (...) a cruel and inhuman law with the objective of exterminating a group: the Gypsies (author's translation). 
In parallel to what Doughty does in her novel, Heredia Maya opposes the emotional denouncing voice of the Gitanos, which dominates the poems, to the historical legal texts, that are quoted word for word. The legal documents range from the fifteenth to the twentieth century, giving evidence of the institutional persecution that Roma have suffered in Spain over the centuries.

However, historical artifacts are not the only source of information for writers, who also delve into the collective memory of the group in order to reconstruct their past. In the last few decades, recalling and representing traumatic memories has been crucial in shaping Romani legal discourse, hence the recent memory activism within the ethnopolitical Romani movement. The practice of creative writing by some of those who lived or witnessed distressing events has not only been a valuable therapeutic exercise but has also provided an archive of testimonials that offer an embodied account of the historical episodes. It is not surprising that these texts usually present a hybrid composition as they display a number of elements that belong to different discourses such as legal, anthropological, psychological, historical, or political. The recollection, organization, and representation of trauma allows survivors to make sense of a rather incomprehensible experience. Narrating a traumatic event offers a possible account of the psychological and social effects it had on those individuals and groups who endured it (Caruth 1995, 153). Shaping a cultural narrative of the mass trauma suffered by Romani peoples allows for its integration into collective memory, compensating for the silences of mainstream historiography. As Paul Ricœur pointed out, any exercise of memory that lack the imperative of justice would be futile $(2004,86-89)$; and in this sense the texts about the Holocaust are implicitly political and justiceseeking. In parallel, prominent historian Dominik LaCapra argues that recovering and representing trauma goes well beyond the individual psychological sphere, reaching the social and political ones, and dialoguing with historical accounts (2014, xii-xiii). Implicitly, all cultural artifacts in which trauma is represented denounce the violence that simmers in the societies in which minority ethnic groups are abused. In this sense, the representation of trauma gives the literary text a denouncing tone that intensifies its political quality.

During his later years, Mateo Maximoff (1917-1999) worked on two narrative pieces whose central point is the persecution and genocide that the Roma suffered under the Nazi regime: the novel Dites-le avec des pleurs (Tell it with tears) and the memoir Routes sans roulottes (Roads without caravans). Born in Barcelona to a Kalderash father and a Manouche mother, Maximoff is today considered one of the founders of Romani literature. He lived most of his life in France, where he became an activist and writer, choosing French as his literary language despite speaking Romanes. His legacy is made of a homogeneous collection of novels that delve into the culture, history, and experiences of Roma. Most of these were edited and published by the author himself, and some of them still are distributed today thanks to the determination of his family.

In Dites-le avec des pleurs, a novel with autobiographical elements, the narrative follows a somewhat time-based logic that begins with the origins and birth of Mateï - an alter-ego of the author - moving gradually to his experiences during the Second World War. Maximoff does not want to leave any room for ambiguity and the novel begins in a German concentration camp in which Matei is imprisoned at the age of $26 .{ }^{[5]}$ As a whole, the novel intends to counteract institutional silence about the Roma genocide, while

5 As far as we know, Maximoff was interned intermittently in a number of concentration camps in southern France, but never in Germany, so this particular experienced is not autobiographical. 
finding genuine ways to represent the horror of war. The textual space allows the writer to sort out the extent of what can be transferred with words; the exercise of memory and the representation of distress and suffering has a clear political tone that is conferred by the very events that are recollected and by the nature of their textual representation.

Maintenant que les Allemands nétaient plus là, les journaux commencaient à parler du massacre des Juifs dans les camps de concentration, les camps d'extermination et leurs sinistres fours crematories. Mais aucun journal ne faisait la moindre mention du massacre des plus de cinq cent mille Tziganes (184). ${ }^{[6]}$

More than 40 years after the end of the Second World War, memory assisted the author in tracing his life between 1917 and 1944 in occupied France. Still, the scope of the novel represents the life and fate of European Roma under the Nazi regime. Aware of the perils of restricting the narrative to his own recollection of events, Maximoff inserts oral accounts that friends and family members disclosed to him in the past. Following the Romani oral tradition, these stories are part of the collective memory of the group, and they are revered for the valuable knowledge they carry. Memory is an essential skill in traditional Romani oral culture, and Maximoff uses it here to represent the history of the Roma as a plural but distinct ethnic group. In order to enhance this, the second part of the novel finishes with the inclusion of a transcribed speech by Bogomila Michalewicz in which she gives account of the brutal fate suffered by Roma in Poland. Michalewicz, as a Romani woman, sociologist, and activist, inserts testimonies of other Roma that witnessed the genocide in her own speech. Furthermore, in the third part of the novel, Maximoff transcribes and translates three interviews in Romani that he recorded with Roma who suffered during the war. At the end, Maximoff declares:

Deux ou trois témoignages ne suffiraient pas à éclairer d'une sinister lumiére la misère des camps Nazis. Pendant leur internement, pas ou peu de Roms savaient lire et écrire. Que de témoignages niauraient-ils pas pu raconter, ceux qui ont eu le bonheur de sortir vivants de cet enfer humain (236). ${ }^{[7]}$

The plurality of memories and accounts create a spiral structure within the novel that reveals the importance of oral tradition and of factual experiences for the production of a Romani memory archive. At the same time, Maximoff implements this strategy for the sake of inclusivity and legitimacy; by inserting other voices in his novel, he is sorting out the danger that implies to speak for others in justiceseeking narratives (Dawes 2009, 401-2).

6 Now that the Germans were gone, the newspapers started to talk about the execution of Jews in the concentration camps and in the sinister crematorium ovens in the extermination camps, but no journal made any mention of the execution of more than 500,000 Roma (author's translation).

7 Two or three testimonial stories would not be enough to shed light - a sinister one - on the misery of the Nazi camps. During their imprisonment, none or few Roma could read or write, otherwise those who were lucky enough to survive that living hell could have offered many testimonies (author's translation). 
The influence of Romani oral tradition is not only present in the structure and narrative of the novel; Maximoff's compositional style is also highly influenced by oral textuality (Junáková 2006, 22-23). In this sense, the reader is surprised at how some storylines are interrupted or forgotten, or how a number of characters are introduced and never mentioned again. There are representational strategies that are connected to the ways in which oral cultures comprehend and express their experiences of the world: for instance, time references are often vague and they mostly allude to seasonal changes; the description of the characters focuses on their origin and on the specific Romani group to which they belong; and, most significantly, the novel never considers any fact or event that is not related to the author/main character's experiences or to the experiences of his kin, which, as we have mentioned above, have been communicated to him through oral accounts. Maximoff's writing is always set within the Romani horizon and culture, which supports the views and behaviours of the characters, contesting previous exogenous representations of Roma.

\section{Self-representation: Redrawing Roma's Social Representation}

Self-representation in works authored by Roma implicitly discusses the image of this ethnic group in the public sphere, intrinsically asserting their right to have control over it. Still, Romani authors confront a difficult literary challenge, that of building well-rounded and complex characters that can successfully convey the psychological consequences of economic and social discrimination which trap individuals in damaging behaviours that, in turn, feed social prejudices. Like other instances of cultural production, literature provides a social space in which Romani authors can examine their subjectivity and identity, assessing the dimensions, often paradoxical, of their own ethnicity. Romani literary texts operate as multifaceted documents that challenge the silences and misrepresentations that have affected Roma in hegemonic and institutional discourses.

As previously discussed, the narrative in Dites-le avec des pleurs is presented in third person, including occasional references to the author himself. However, the main character, Mateï, is an unambiguous alterego of the author, a surrogacy that allows Maximoff to distance himself from the disturbing experience of remembering the traumatic events of his youth. At the same time, this literary strategy permits the integration in Mateï's biography of experiences that belonged to other members of Maximoff's family or to his Romani friends. Significantly, the fourth chapter of the book opens with the following sentence: “C'est volontairement que l'auteur a choisi de presenter la vie de trois Tziganes parmi des milliers d'autres. Essayons de comprendre pourquoi" (38). ${ }^{[8]}$ Here, narrative voice projects the author as a third person, precisely to highlight with its authority and presumed impartiality that the author has carefully crafted the design of the novel within the limits of kinship. Despite Maximoff not following through with his initial plan, the selection of these three characters is based on their representative quality, since they belong to different

8 The author has willingly chosen to present the life of three Gypsies among thousands of others. Let's try to understand why (author's translation). 
Romani groups. The characters' diverse origins and traditions convey the heterogeneous condition of Roma. At the same time, the novel focuses on how these characters were victims of Nazi genocide for the simple reason of being Roma (39-44).

Similarly, in Goddamn Gypsy, Ronald Lee (1934-2020) presents his own autobiography as a Canadian Kalderash through the character of Yanko, who is conceived as a literary proxy that allows the author to freely recreate his own past. ${ }^{[9]}$ The narrative follows a chronological line that begins in the early 1960s, when Yanko is a young adult, and progresses to the end of the decade. The plot is set in the geopolitical context of eastern Canada, featuring historical events, such as the Quiet Revolution in Quebec or the organization of the 1967 World Expo in Montreal. Early on in the novel, Yanko recounts how he grew up with gadje and received formal education, a process that detached himself from a culture -Romani- that was rightfully his by birth, placing him in a liminal space (27) and conferring a hybrid identity that he seems to regret but cannot escape. Aidan McGarry echoed this point when he pointed out that usually Roma display a hybrid identity as they inhabit more than one culture at the same time (770).

Inspired by Jack Kerouac's On the Road, Lee depicts Yanko's journey as one of recovery. Determined to regain his native romité, ${ }^{[10]}$ he undergoes a symbolic christening, becoming a newborn Rom (31). After this, the narrative follows the process of repossession of those traits that Yanko considers would make of him a true Rom, such as command and preservation of the Romani language (30), and the knowledge of the history of his people, which emphasizes the events that took place during the Holocaust. As in the case of Maximoff's work, the main character of Lee's novel builds on the author's experiences while reflecting on how to live within Romani culture, from the use and appreciation of Roma's specific language, to the preservation and recognition of their ancestral beliefs and practices.

The literary text opens up a space of reflection in which Roma can rethink the relational nature of representations and produce new alternatives, having an impact on both Romani and non-Romani readers as they reframe Romani public identity (McGarry 769). Still, self-representation is not free of contradictions, as it might be conditioned from existing internalized social prejudices. Nicolae Gheorghe rightly pointed out that self-representation might in fact fulfill some of the general expectations of what Roma are supposed to be and do $(2013,50)$. In this sense, the depiction of cultural practices gives depth to the novel's characters, whose viewpoint and behaviour reflect the complexity of their beliefs and values, establishing therefore a clear ethnic ethos.

9 In 2009, Magoria Books reedited the novel under a new bilingual title E Zhivindi Yag/The Living Fire. In the preface that accompanies this edition, Lee claims that his original proposed title was indeed The Living Fire, but it was rejected (viii), presumably by the editors.

10 This concept, used by Courtiade (1990, xv), conveys the idea of the Romani ethos that we are implementing in this article. Other critics have adapted this term to their own context and languages, such as the notion of "gitanidad" used by Sergio Rodríguez in his study of Spanish Gitanos. 


\section{Romani Culture and Language}

Romani authors are paying extensive attention in their work to particular ways of living in their communities, conveying the depth of their cultural identity and simultaneously contesting previous misconceptions that have long affected Roma's social representation. The four literary works that we discuss in this article offer information about the norms, beliefs, and values that shape Roma's behavior, both in private and social spaces. This material becomes instrumental in establishing a Romani ethos, as it examines the particular viewpoints and features that are characteristic of, and often exclusive to, Romani culture. The references to these aspects are often illustrated with details about their particular material culture, and they disclose exceptional information about the lives of Roma, such as the spaces they inhabit or the tools they use for domestic or professional purposes.

As discussed earlier, the interest of Maximoff in Dites-le avec des pleurs is to denounce the Holocaust and its dreadful consequences for European Romani communities. The storyline, diversions included, focuses on depicting characters that endured, directly or indirectly, the Holocaust and the waves of repression that preceded and followed it. These characters usually are outlined in terms of their ethnic identity, and in this sense the author offers detailed information about their ways of life. Since the characters belong to different Romani groups, Maximoff points out the existing disparity in terms of practices, conveying the heterogeneity that the general ethnic label might otherwise hide. This information often is inserted within the plot of the novel, following the life of Matei. For example, one of the most characteristic topos of Romani folklore, that of the mula - dead people or spirits - and the afterlife, is presented within the storyline that retrieves the most significant episodes of Mateïs early years.

\section{[...] Lutka s’adressa à quelqu'un que Mateï ne voyait pas: \\ - Va-t-en, Poleskina!}

En entendant le nom de sa mère, Mateï leva la tete. Sa mère nétait-elle donc pas morte? Puis la grand-mére parla de nouveau:

- Laisse ton petit tranquille! (49). ${ }^{[1]}$

Cleverly, the narrator does not address directly a topic that would certainly shake the logic of many of his readers; he presents it through the direct experience of Mateï, who witnessed a conversation between his grandmother and his deceased mother, initially problematizing it but later accepting this without further questions. This narrative strategy is also implemented in the works of Doughty and Lee, which are both particularly rich in terms of the anthropological information they insert within their plots. In particular, Fires in the Dark is an extraordinary catalogue of the rituals and beliefs of Central Europe's Romani community. The ethnological information is skillfully embedded in the storyline, conveying how cultural practices are not only internalized and embodied but also intrinsically connected to the survival of the individual and the group. Thus, the adherence to the rules of the Marimé code, which might be 
considered odd for outsiders, is self-explained in the narrative by the circumstances of deprivation and neediness that plague the characters' lives. ${ }^{[12]}$ In this sense, in becomes clear that the defiled - marimé - condition of Anna after childbirth and the mandatory two-weeks post-partum isolation allow her to bond with her newborn, giving her time to rest and heal. In the context of Anna and her group's life, which is characterized by daily exertion through physical work, this seclusion improves the chances of survival for both mother and newborn.

The narratives of these novels also offer key information about the objects used by Roma in their daily lives. In Goddamn Gypsy, Ronald Lee inserted a number of Tarot cards that enlighten avant la lettre the storyline of Yanko's journey. These cards, expressly drawn for the novel by one of Lee's relatives (Mudure 2009, 308), deliver a Romani version of the Tarot since the figures either are embodied by Roma or they refer to their folklore. They are also accompanied by an explanation that elucidates its meaning within Romani culture and within the novel's narrative.

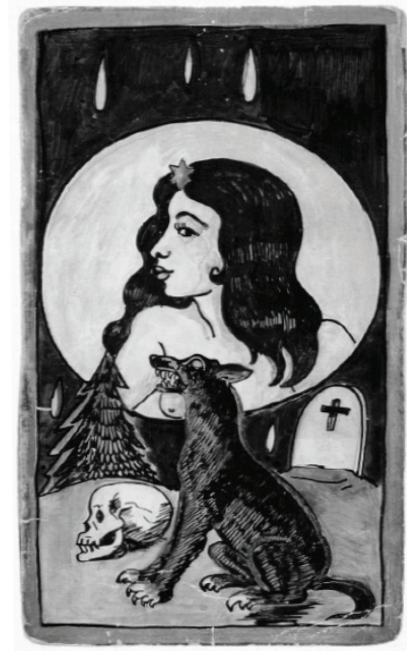

E De Devleski, or Earth-Mother card. This is primarily the card of the dreamer, the seeker after illusions and the youth searching for the answer to the riddle of life. It also carries a warning for man not to meddle with the secret mysteries of nature which can bring either good or evil results. It is the card of the romantic, the artist, the thinker and the student, but not of the realist. (...) This is Yanko as he sets out on his journey (xii-xiii).

Divination cards are surely an important element in Romani material culture, since they have been used for generations as a professional tool. In this regard, the novel refers in several instances to characters, usually women, whose main activity is fortune-telling (81), a customary economic activity in most Romani groups.

As it follows Yanko's journey of learning Romani ways, Goddamn Gypsy recurrently gives details of rituals associated with transitional experiences, such a birth or marriage, or it describes ceremonial rites, such as the kris (Romani court) or the celebration of a pakiv (welcoming party for special guests). In particular, Lee's novel emphasizes the importance of music in Romani culture, as it serves many purposes, from

12 As defined by Ronald Lee himself "The marimé code (Romaniya) is a complicated system of taboos concerning areas of pollution and defilement. It also embraces a Gypsy’s personal behavior towards his fellows (...)” (2001, 203). 
economic to spiritual. On several occasions, the text integrates songs as part of the oral culture that keeps alive the memory of critical historical experiences, such as that of the Holocaust (62).

Likewise, Camelamos naquerar considers music a wholly embodied element of Gitano culture. All the characters in this piece express themselves through flamenco singing and dancing, embodied practices that reveal their history and social experiences. Heredia Maya explicitly indicates how the experience of oppression and marginalization are at the heart of flamenco (9).

Finally, the use of Romanes becomes a quintessential element in these literary works as it reinforces their romité even when they are written in another language. During the last decades, Romani has become a notorious mark of authenticity, regardless of the fact that there is a significant degree of disparity among different dialects and that some communities have long lost the ability to speak it. Djuric states that "la langue romani est la patrie rom la plus vraie, la plus exacte" ${ }^{[13]}$ (1990, vii); and, in the same note, Ian Hancock refers to a Romani saying: Amari čhib s'amari zor "our language is our strength" $(2002,139)$, as he points out that the use of Romani is a critical mark of identity. Indeed, the works we are discussing here make use of this language in different ways, further increasing their hybrid and heterogeneous character. Maximoff and Doughty periodically employ Romani terms when these bear a particular meaning or do not have a direct translation into the language of the text. Maximoff usually prefers to translate these terms directly into the text: "Les roulottes (les vourdona) étaient stationnées entre deux villages, au bord d’un ruisseau" (22), or "Les jeunes, les ternear (jeunes à marier) emmenaient les chevaux dans les près [sic]" (60). ${ }^{[14]}$ Doughty usually leaves in the text the original term, inviting the reader to deduct its meaning with the information provided:

No other farmer in the whole of Bohemia employed as many Roma as Ctibor Michálek. His harvests had become famous as a place for the vitsas to meet and exchange news, for marriage agreements and the settling of debts. A series of divanos would be held throughout the harvest to settle disputes, lasting all the long, long evenings... (44).

Likewise, Heredia Maya occasionally inserts in his text Caló terms or sentences that he translates in footnotes:

\author{
Mira que flamenco, prima, \\ mira que gitano soy, \\ pena el crayí que me naje \\ yo con mi gente me estoy (25). ${ }^{[15]}$
}

13 “The Romani language has become the real Romani fatherland, the right one" (author's translation).

14 "The wagons (the vardos) were parked between two villages, near a creek"; "The young girls, the ternear (young girls to be married) took the horses to the moor".

15 "Look, girl, how flamenco I am/look, how Gitano I am,/the king says I should leave/but I'm staying with my people". The first, second, and last verses of this poem are written in Spanish, and the third one is in Caló, which Heredia Maya translates with the help of a footnote. This third verse is incomprehensible to the average Spaniard reader. The Spanish term primo- $a$ means "cousin", but Gitanos use it to address and to refer to other members of their ethnic community who are not older than themselves; otherwise, they would use the term tío- $a$ (uncle or aunt). The poetic voice identifies himself as Gitano and flamenco, addressing the girl in order to impress her with these features. 
In the case of Ronald Lee, his life-long dedication to the Romani language seeps constantly throughout the pages of Goddamn Gypsy, both at the textual level and in the storyline. Within the actual English text, Lee makes abundant use of Romani sayings, sentences, or words that he subsequently translates. At the same time, very early on in the novel Yanko displays a keen interest in his people's language, as he observes and takes notes when other characters speak it in front of him. In fact, one of Yanko's main cultural projects is to create a Romani dictionary, a topic that is discussed in several chapters of the novel.

\section{Conclusion}

Given the wide adoption of the narrative of the Romani diaspora by civil and political organizations, the study of literary texts within a transnational scope offers a compelling view of how this narrative is being developed in cultural texts that emerge in different communities and national settings. This transnational scale might indeed entail some methodological challenges, since there is a limited amount of translated works, a problem that affects not only creative writing but also academic and critical analyses.

The concept of ethos implemented in this article supports the delimitation and analysis of some of the common traits that works authored by Roma exhibit. Within the restricted scope of a research article, I have examined how literary texts depart from and recreate a specific Romani ethos through the recovery of an untold history, self-representation, and the reaffirmation of a misconstrued culture. The analysis of this ethos could expand to other features of Romani culture that enter creative writing and shape distinctive traits. Since ethos, as defined by Reynolds, is an ongoing social product (327), the literary texts reveal the values and discourses that characterize a community in a given space and time. In this sense, certain cultural and social topoi, such as nomadism, the notion of India as a mystic original place, or that of a Romani nation, among others, should be considered, as well as questioned, as part of the Romani ethos. 


\section{References}

Baumlin, James S., and Craig A. Meyer. 2018. "Positioning Ethos in/for the Twenty-First Century: An Introduction to Histories of Ethos". Humanities 7 (3): 78. https://doi.org/10.3390/h7030078

Blandfort, Julia. 2013. "Remnants of Auschwitz. Romani Narratives and the Aesthetics of Holocaust". The Holocaust in History and Memory 6: 107-116. https://www1.essex.ac.uk/history/journal_thhm/volume_6.html

- 2015. Die Literatur der Roma Frankreichs. Berlin: De Gruyter.

Caruth, Cathy. 1995. Trauma. Explorations in Memory. Baltimore: The John Hopkins University Press.

Courtiade, Marcel. 1990. "En guise de preface. Interview avec Rajko Djuric”. In Sans maison Sans tombe/Bi Kheresqo Bi Limoresqo by Rajko Djuric. Paris: L’Harmattan.

Dawes, James. 2009. "Human Rights in Literary Studies". Human Rights Quarterly 31 (2): 394-409. https:// 10.1353/hrq.0.0071

Djuric, Rajko. 1990. Sans maison Sans tombe/Bi Kheresqo Bi Limoresqo. Paris: L’Harmattan. 2002. Die Literature der Roma und Sinti. Berlin: Parabolis.

Doughty, Louise. 2005 [2003]. Fires in the Dark. New York: Harper Perennial.

French, Loreley. 2015. Roma Voices in the German-Speaking World. New York: Bloomsbury.

Gheorghe, Nicolae. 2013. "Choices to Be Made and Prices to Be Paid: Potential Roles and Consequences in Roma Activism and Policy-making". In From Victimhood to Citizenship. The Path or Roma Integration, edited by Will Guy, 40-97. Budapest: Central European University Press.

Hancock, Ian. 2002. We Are the Romani People. Hatfield: University of Hertfordshire Press.

Hancock, Ian, Siobhan Dowd, and Rajko Djuric, eds. 1998. The Roads of the Roma. A PEN Anthology of Gypsy Writers. Hartfield: University of Hertfordshire Press.

Heredia Maya, José. 1976. Camelamos naquerar. Granada: Secretariado de publicaciones de la Universidad de Granada.

Huyssen, Andreas. 2015. "Memory Culture and Human Rights". In Historical Justice and Memory, edited by Thompson and Neumann, 27-44. Madison: University of Wisconsin Press.

Junáková, Dana. 2006. Le Samudaripen dans l’ouvre de Matéo Maximoff. B.A. Thesis. Brno, Masaryk University.

Kenrick, Donald. 2007. Historical Dictionary of the Gypsies (Romanies). Lanham, Toronto, Plymouth: The Scarecrow Press.

LaCapra, Dominick. 2014. Writing Trauma. Writing History. Baltimore: John Hopkins University Press.

Lee, Ronald. 1971. Goddam Gypsy. An Autobiographical Novel. Montreal: Tundra Books.

_ 2009. "Preface." In The Living Fire by Ronald Lee, vii-x. Magoria Books: Toronto. https://www. magoriabooks.com

- 2011. “The Rom-Vlach Gypsies and the Kris-Romani”. In Gypsy Law. Romani Legal Traditions and Culture, edited by Walter O. Weyrauch, 188-230. Berkeley and Los Angeles: University of California Press.

McGarry, Aidan. 2014. "Roma As a Political Identity: Exploring Representations of Roma in Europe”. Ethnicities 14 (6): 756-774. https://doi.org/10.1177/1468796814542182 
Maximoff, Matéo. 1990. Dites-le avec des pleurs. Champigny-sur-Marne: author's edition.

Mudure, Mihaela. 2009. “Ronald Lee: A Canadian Roma Writer”. Language and Literature. European Landmarks of Identity (Conference proceedings). Pitesti, Pitesti University Press. 306-312.

Reynolds, Nedra. 1993. "Ethos As Location: New Sites for Understanding Discursive Authority”. Rhetoric Review 11 (2): 325-338. https://doi.org/10.1080/07350199309389009

Ricœur, Paul. 2004. Memory, History, Forgetting. Chicago: University of Chicago Press.

Rodríguez, Sergio. 2010. Gitanidad. Otra manera de ver el mundo. Barcelona: Kairós.

Smith, Ruby. 2018. “Talk to Me: A Conversation Special”. Travellers Times. https://www.travellerstimes.org.uk/ news/2018/04/talk-me-conversation-special-romani-author-louise-doughty-meets-ruby-smith

Toninato, Paola. 2014. Romani Writing. Literacy, Literature and Identity Politics. New York and London: Routledge.

Vermeersch, Peter. 2006. The Romani Movement. Minority Politics and Ethnic Mobilization in Contemporary Central Europe. New York: Berghahn Books.

Weyrauch, Walter O. 2001. “Romaniya: An Introduction to Gypsy Law”. In Gypsy Law. Romani Legal Traditions and Culture, edited by Walter O. Weyrauch, 1-10. Berkeley and Los Angeles: University of California Press.

Zahova, Sofiya. 2016. "Roma Literature: Historical Developments and Challenges of Internationalization”. In Roma Culture: Myths and Realities, edited by Elena Marushiakova and Vesselin Popov, 81-126. Munich: Lincom.

_ 2020. "Romani Language Literature." In The Palgrave Handbook of Romani Language and Linguistics, edited by Yaron Matras \& Anton Tenser, 539-569. Cham (CH): Palgrave Macmillan. 